\title{
Development of Planar Metal Supported SOFC with Novel Cermet Anode
}

Blennow Tullmar, Peter; Hjelm, Johan; Klemensø, Trine; Persson, Åsa Helen; Brodersen, Karen; Srivastava, Akhilesh Kumar; Frandsen, Henrik Lund; Lundberg, Mats; Ramousse, Severine; Mogensen, Mogens Bjerg

Published in:

E C S Transactions

Link to article, DOI:

10.1149/1.3205585

Publication date:

2009

Document Version

Publisher's PDF, also known as Version of record

Link back to DTU Orbit

Citation (APA):

Blennow Tullmar, P., Hjelm, J., Klemensø, T., Persson, Å. H., Brodersen, K., Srivastava, A. K., Frandsen, H. L., Lundberg, M., Ramousse, S., \& Mogensen, M. B. (2009). Development of Planar Metal Supported SOFC with Novel Cermet Anode. E C S Transactions, 25(2), 701-710. https://doi.org/10.1149/1.3205585

\section{General rights}

Copyright and moral rights for the publications made accessible in the public portal are retained by the authors and/or other copyright owners and it is a condition of accessing publications that users recognise and abide by the legal requirements associated with these rights.

- Users may download and print one copy of any publication from the public portal for the purpose of private study or research.

- You may not further distribute the material or use it for any profit-making activity or commercial gain

- You may freely distribute the URL identifying the publication in the public portal 


\title{
Development of Planar Metal Supported SOFC with Novel Cermet Anode
}

\author{
Peter Blennow, Johan Hjelm, Trine Klemensø, Åsa Persson, Karen Brodersen \\ Akhilesh Kumar Srivastava, Henrik Lund Frandsen, Mats Lundberg \\ Severine Ramousse, Mogens Mogensen
}

Fuel Cells and Solid State Chemistry Department, Risø National Laboratory for Sustainable Energy, Technical University of Denmark, DK-4000 Roskilde, Denmark

\begin{abstract}
Metal-supported solid oxide fuel cells are expected to offer several potential advantages over conventional anode (Ni-YSZ) supported cells, such as increased resistance against mechanical and thermal stresses and a reduction in materials cost. When Ni-YSZ based anodes are used in metal supported SOFC, electrode material from the active anode layer may interdiffuse with the metallic support during sintering. The purpose of this work is to illustrate how the interdiffusion problem can be circumvented by using an alternative anode design based on porous and electronically conducting layers, into which electrocatalytically active materials are infiltrated after sintering. The paper presents the recent results on the electrochemical performance and durability of the novel planar metal-supported SOFC design. The results presented in the paper show that the novel cell and anode design has a promising performance and durability at a broad range of temperatures and is especially suitable for intermediate temperature operation.
\end{abstract}

\section{Introduction}

Solid oxide fuel cells (SOFC) are high temperature electrochemical devices, which convert the energy of a chemical reaction directly into electrical energy. They are normally operated between $600-1000^{\circ} \mathrm{C}$ and since high efficiencies can be reached, also for quite small fuel cell units, this technology is attractive for energy conversion systems. However, there are some drawbacks which have caused a slow introduction of SOFCs on the energy market. One of the main problems is the choice of materials in relation to costs. Much of the development of SOFC technology has generally been devoted to reduce the thickness of various cell components. Furthermore, the various components comprising an SOFC are constantly being refined and improved with the overall aim of achieving higher and more stable electrochemical performance with various fuels, while lowering the cost.

The primary challenges to be solved, before fuel cells can achieve a breakthrough on the consumer market, are costs and durability. Investigating different materials and finding new ingenious solutions in design engineering are a few key factors that could make it possible. Low temperature operation $\left(500-800^{\circ} \mathrm{C}\right)$ exhibit advantages such as wider choice of component materials (including metals), improved stability, increased material durability and overall device robustness. All these factors aim at crucially lowering the cost of the SOFC device. 
Metal supported SOFCs are believed to offer an alternative to conventional electrodeand electrolyte-supported SOFCs. They have many potential advantages such as good thermal conductivity and ductility of the metallic substrate, which may both improve thermal shock resistance, and lower the internal temperature gradients, allowing quicker start-up (1). The metal supported SOFCs also offer low-cost material alternatives compared to traditional all-ceramic-based devices. Furthermore, they have different mechanical behavior, compared to ceramic components, which makes them potential candidates for withstanding the mechanical stresses e.g. generated by the severe vibrations when a stack is incorporated into systems used for transport applications. Despite these potential advantages, processing challenges have been the major issue holding back the development of metal supported SOFCs. One of the most important issues is the densification of the electrolyte layer that normally requires high sintering temperatures (normally $>1200^{\circ} \mathrm{C}$ ). These high temperatures tend to lead to serious corrosion of the metallic substrate. To solve the problem, different processing routes to fabricate electrodes and dense electrolytes on metallic supports have been employed, such as atmospheric plasma spray processing (APS) $(2,3)$, vacuum plasma spraying (VPS) (4-7), pulsed laser deposition (PLD) (8), electrophoretic deposition (EPD) (9), and high temperature sintering in reducing atmosphere $(1,10,11)$.

Most developers of metal supported SOFCs use anodes that are a ceramic-metallic composite (cermet) of yttria-doped zirconia (YSZ) and nickel. However, at elevated temperatures nickel tends to agglomerate and sinter, resulting in a degradation of the anode performance with time. Furthermore, when Ni-YSZ based anodes are used in metal supported SOFC, electrode material from the active anode layer may interdiffuse with the metallic support during sintering or during high temperature operation. Interdiffusion causes formation of a $\mathrm{Ni}-\mathrm{Cr}-\mathrm{Fe}$ alloy in the anode layer, which is detrimental to cell performance and stability (see e.g. (12) and references therein).

Infiltration of various materials has recently been introduced for use in SOFC electrodes. Infiltration with ceria-based nano-particles, in Ni-YSZ based anodes, has showed sustained sulphur tolerance when operating on humidified $\mathrm{H}_{2}$ fuel containing 40 ppm $\mathrm{H}_{2} \mathrm{~S}$ (13). Infiltration of $\mathrm{Ni}$ and $\mathrm{LSM}\left((\mathrm{La}, \mathrm{Sr}) \mathrm{MnO}_{3}\right)$ in porous YSZ backbone structure for the use as anode and cathode, respectively, in metal supported SOFC has been successfully demonstrated by Tucker et. al. (1). They fabricated a five-layer structure consisting of porous metal-support/porous YSZ interlayer/dense YSZ electrolyte film/porous YSZ interlayer/porous metal current collector. After sealing the cell to a cell housing/gas manifold the porous YSZ interlayers were infiltrated with Ni and LSM catalyst precursor solutions at low temperature prior to cell testing. This fabrication route avoided undesirable decomposition of LSM, Ni coarsening, and interdiffusion between $\mathrm{Ni}$ catalyst and $\mathrm{FeCr}$ in the support (1). However, the power output of a cell with as-infiltrated $\mathrm{Ni}$ anode degraded rapidly during initial operation. This degradation was attributed primarily to coarsening of the fine infiltrated Ni particles (10). It has recently been demonstrated that it is possible to improve the performance for hydrogen oxidation by several orders of magnitude through surfactant-assisted infiltration of a Gd-doped ceria phase (CGO) into an electronically conductive backbone phase consisting of $\mathrm{Nb}$-doped $\mathrm{SrTiO}_{3}(\mathrm{STN})$, which after low-temperature calcination form nano-sized CGO particles on the surface of the electronically conductive backbone structure (14). It was shown that the electrochemical activity was maintained or even improved compared to Ni/YSZ fuel electrodes. The electrocatalytic activity and oxygen 
ion transport was believed to be provided by the CGO nano-particle network covering the STN backbone structure whereas the STN backbone structure mainly provided electronic conductivity (14).

Based on the abovementioned challenges with interdiffusion in the $\mathrm{Ni}-\mathrm{Fe}-\mathrm{Cr}$ system and $\mathrm{Ni}$ coarsening during operation, this paper presents the development of metal supported cells with a novel design where these problems can be circumvented by using an alternative anode structure. The cell design is based on porous and highly electronically conducting layers into which electrocatalytically active anode materials (CGO and minor amounts of Ni) are infiltrated after sintering. The metal supported cells are developed for operation at lower temperatures in the range $600-750^{\circ} \mathrm{C}(15)$. Furthermore, the cell design is based on a multilayered structure obtainable by conventional ceramic processing techniques.

\section{Experimental}

Sample Fabrication

The metal powder was selected regarding particle size distribution suitable for tape casting. The slurry was based on organic solvent and contained, in addition to the Fe-Crpowder, binder, plasticizer, and other organic additives necessary for the fabrication process. Some metal-based slurries were also fabricated with $0-50$ vol. \% Y-doped $\mathrm{ZrO}_{2}$ (YSZ) with respect to metal powder to, after tape-casting, form a so called cermet (ceramic + metal) layer (see Figure 1) of various thicknesses. Similar conventional ceramic processing techniques have been used to fabricate thin electrolyte tapes based on Sc- and Y-doped $\mathrm{ZrO}_{2}$ (from here on referred to as ScYSZ). After drying, the tapes were laminated together and cut to desired shape. Thereafter, the half cells were heat treated in air for debinding followed by co-sintering in reducing atmosphere $\left(\mathrm{H}_{2} / \mathrm{Ar}\right)$. After cosintering, the electrocatalytically active phase (to work as fuel electrode) was infiltrated into the porous structure (see more details below). Similar fabrication route was used to fabricate symmetrical cells of cermet layer/electrolyte (thick)/cermet layer. These symmetrical cells were used to investigate the electrochemical performance of the anode structure in an one atmosphere set-up.

As a final step in the fabrication of a fully functional metal supported SOFC, the cathode layers have been applied by screen printing of $\mathrm{La}_{0.58} \mathrm{Sr}_{0.4} \mathrm{Co}_{0.2} \mathrm{Fe}_{0.8} \mathrm{O}_{3-\delta} / \mathrm{Ce}_{0.9}$ $\mathrm{Gd}_{0.1} \mathrm{O}_{2-\delta}(\mathrm{LSCF} / \mathrm{CGO})$ composite powders.

\section{Catalyst Infiltration}

The infiltration of electrocatalysts basically followed the procedure set forth in ref. (14). Table I shows the different compounds that were investigated by infiltration in symmetrical cells.

TABLE I. Prepared infiltration solutions.

\begin{tabular}{lc}
\hline Target compound & Abbreviation \\
\hline $\mathrm{CeO}_{2}$ & $\mathrm{CeO}_{2}$ \\
$\mathrm{Ce}_{0.8} \mathrm{Gd}_{0.2} \mathrm{O}_{2-\delta}$ & $\mathrm{CGO} 20$ \\
$\mathrm{Ce}_{0.8} \mathrm{Gd}_{0.2} \mathrm{O}_{2-\delta}+10 \mathrm{wt} \% \mathrm{Ni}$ & $\mathrm{CGO} 20-\mathrm{Ni}$ \\
\hline
\end{tabular}


Only the most promising infiltration solution $\left(\mathrm{Ce}_{0.8} \mathrm{Gd}_{0.2} \mathrm{O}_{1.9}(\mathrm{CGO} 20)+10\right.$ wt. $\% \mathrm{Ni}$ (with respect to $\mathrm{CGO} 20$ ), $\mathrm{CGO} 20-\mathrm{Ni}$ ), based on electrochemical performance as an fuel electrode in symmetrical cell tests (see details below), was further tested for infiltration in half cells with successive application of cathode layers followed by cell testing. The prepared solutions were infiltrated into the open porosities of the co-sintered samples using vacuum-assisted infiltration. After infiltration, the cells were calcined at $350^{\circ} \mathrm{C}$ in air for $2 \mathrm{~h}$. The amount of infiltrated material in the porous electrodes was estimated by weighing the cells before and after impregnation and calcination. The approximate weight of the electrolyte was subtracted to get wt.\% of infiltrated material in the electrode.

\section{Microstructural Characterization}

The microstructure of the samples, both before and after electrochemical characterization, was investigated on fractured cells and on polished cross-sections with a Zeiss Supra 25 scanning electron microscope (SEM) equipped with an x-ray energy dispersive spectrometer (XEDS) and with a Hitachi TM1000 tabletop SEM.

\section{Electrochemical Characterization}

Symmetrical Cell Tests. The as-fabricated symmetrical cells (cermet layer / electrolyte (thick) / cermet layer) were cut into smaller pieces $\left(0.6 \times 0.6 \mathrm{~cm}^{2}\right)$ followed by infiltration of materials according to Table I. The electrode polarization resistance $\left(\mathrm{R}_{\mathrm{P}}\right)$ of the various infiltrated electrodes was then characterized by electrochemical impedance spectroscopy (EIS) in a one-atmosphere set-up. Measurements have been conducted between $600-800^{\circ} \mathrm{C}$ in various atmospheres with humidified $\mathrm{H}_{2} / \mathrm{N}_{2}$ gas mixtures. Before EIS measurements, Pt-paste was applied onto the electrodes to obtain a current collection layer. The impedance spectra of the symmetrical cells were obtained at open circuit potential (OCP) with a Solartron $1260 \mathrm{FRA}$ (frequency range $1 \mathrm{MHz}-50 \mathrm{mHz}$ with $25 \mathrm{mV}$ amplitude). The impedance data were analyzed with ZSimpWin software (EChem Software).

Fuel Cell Tests. The fuel cell performance of a metal supported cell infiltrated with CGO20-Ni have been investigated. The tested cell was a button cell $\left(2 \times 2 \mathrm{~cm}^{2}\right.$ sized pieces) with an active area of $0.5 \mathrm{~cm}^{2}$ (defined by the screen-printed cathode layer). Ptmesh and Pt-paste was applied on both electrodes as current collector and a combination of gold rings and glass were used as seals between the cell and the alumina tubes (containing the gas supply and electrical wiring). I-V curves were conducted between 650 $-800{ }^{\circ} \mathrm{C}$ in various atmospheres with water-saturated (at ambient temperature) $\mathrm{H}_{2} / \mathrm{N}_{2}$ gas mixtures on the anode side and air or oxygen $\left(\mathrm{O}_{2}\right)$ on the cathode side. Galvanostatic durability testing was also carried out in order to assess the effect of the heat treatment on the electrochemical stability of the cell. Testing was carried out at low fuel $\left(\mathrm{H}_{2}+3 \%\right.$ $\left.\mathrm{H}_{2} \mathrm{O}\right)$ and oxygen utilization $(1-2 \%)$, at $655^{\circ} \mathrm{C}$ and at a current density of $0.25 \mathrm{~A} \mathrm{~cm}^{-2}$. The oxidant gas was air. The measurements were conducted with a Solartron 1255B frequency response analyzer in combination with a Solartron 1287A potentiostat. The setup used for the button cell tests was only used as a screening set-up and was not optimized for detailed electrochemical impedance analysis. Thus, detailed characterization of the polarization resistances was not possible. Measurements are currently being conducted on $5 \times 5 \mathrm{~cm}^{2}$ cells (active area $4 \times 4 \mathrm{~cm}^{2}$ ) where more thorough analysis is possible. These results will be presented in a forthcoming journal paper. 


\section{Results and Discussion}

\section{Microstructural Characterization}

Micrographs of cross-sections of a half cell and a symmetrical cell after sintering (before infiltration) are shown in Figure 1. The micrographs show that the employed fabrication route gives a metal support layer and a cermet layer that are sufficiently porous for gas transport. The electrolyte layer in Figure 1(A) also seemed to be dense, thereby meeting the requirements of gas tightness. The symmetrical cells had similar cermet layer structure compared with the half cells, achieving comparable microstructures with regards to infiltration and electrochemical characterization.
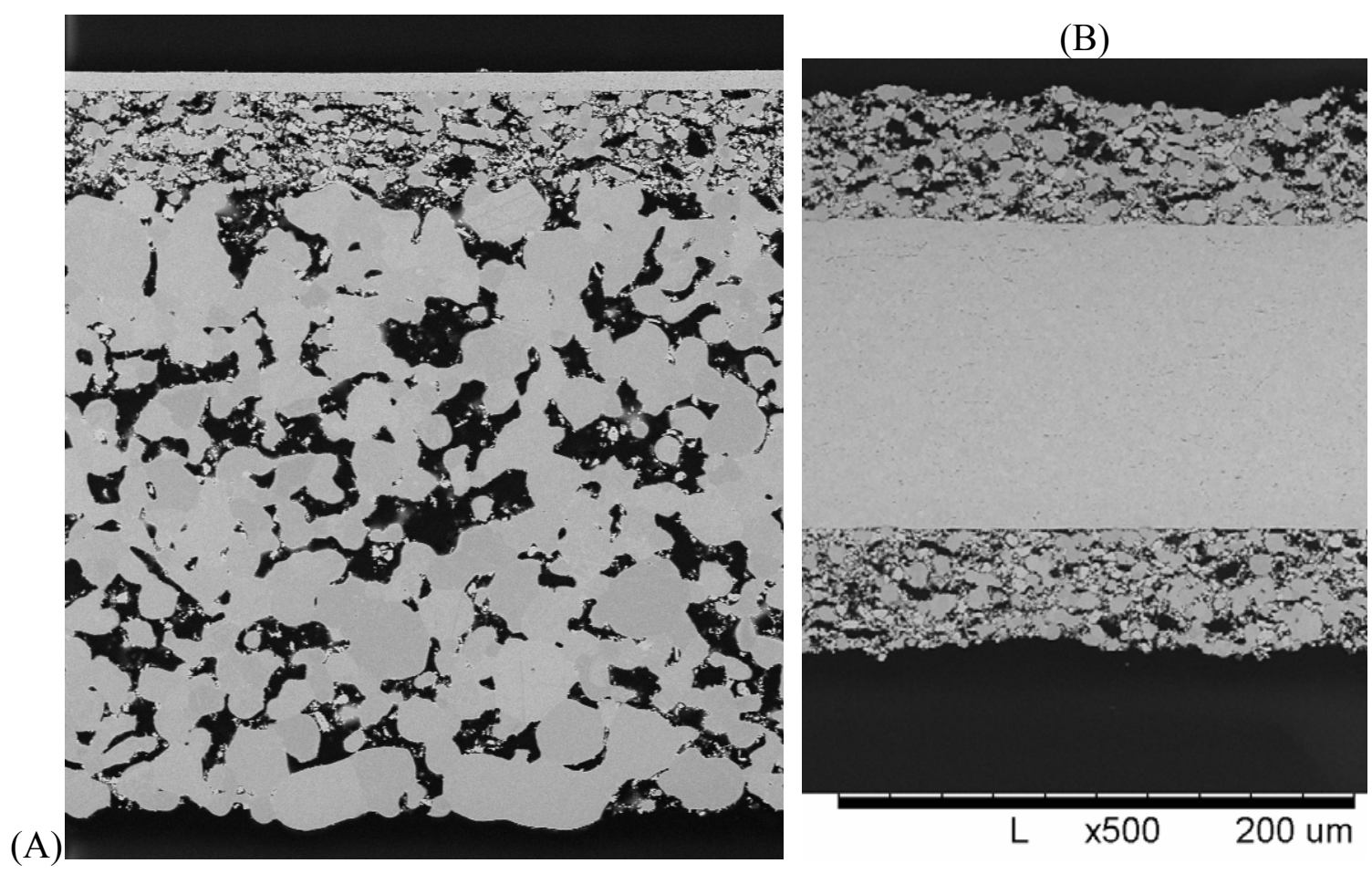

Figure 1. (A) SEM image showing the polished cross-section of the planar metalsupported half cell. The electrolyte is shown in the top, followed by the cermet layer, and the metal support (B) SEM image showing the cross-section of a symmetrical cell of cermet layer/electrolyte/cermet layer before infiltration of electrochemically active material.

Figure 2 displays high magnification SEM images of the microstructure of a fractured symmetrical cell with the cermet layer infiltrated with the CGO20-Ni precursor solution. The nano-sized CGO20-Ni particles completely covered all the cermet particles in the porous microstructure all the way into the electrolyte. The presence of a CGO20 phase was verified with XEDS. Similar microstructures were obtained on the half cells as well but are not shown here. 

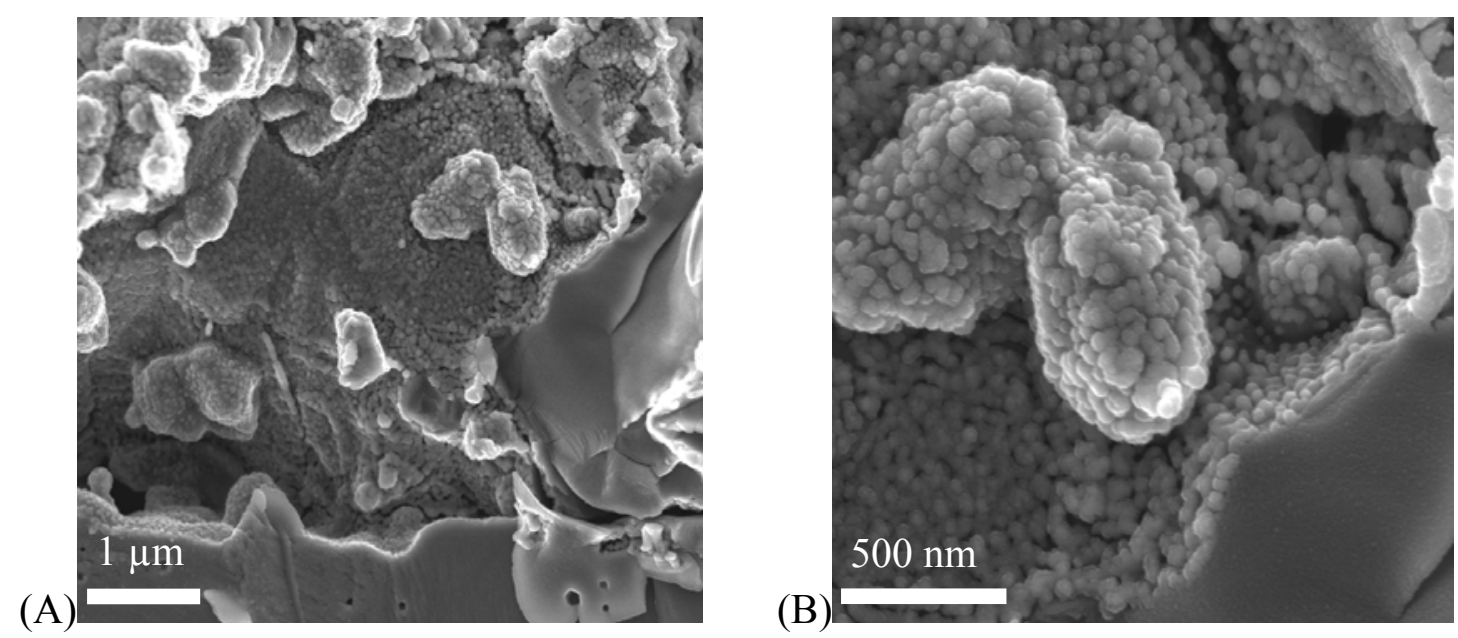

Figure 2. High resolution SEM images at various magnifications showing fractured crosssectional images of CGO20-Ni infiltrated cermet layers (on symmetrical cells). The CGO20-Ni particles are seen as the thin layer $(50-100 \mathrm{~nm})$ covering the surfaces of the larger particles in the cermet layer. Part of the electrolyte is seen at the bottom of image (A). The images were obtained after electrochemical testing with a maximum test temperature of $750^{\circ} \mathrm{C}$.

The amount of infiltrated material in the different samples was calculated by weighing the small symmetrical cells and button cells before and after the infiltration steps. The total amount, irrespective of infiltration solution in Table I, was measured to be $10.5 \pm 1$ wt. $\%$ and $2.4 \pm 0.2$ wt. $\%$ for symmetrical cells and button cells, respectively. The samples infiltrated with CGO20-Ni, had 10 wt.\% Ni with respect to CGO20. The amount of $\mathrm{Ni}$ in the electrodes was thus only approximately $1 \mathrm{wt} . \%$ and $0.2 \mathrm{wt} . \%$ for the symmetrical cells and button cells, respectively. The amount of infiltrated material between symmetrical cells and button cells should not be directly compared due to the difference in porosity/surface area and weight of the metal support layer and cermet layer. Since the infiltration procedure was identical between the different samples, giving similar microstructures of the infiltrated phase (as identified with SEM), the amount of infiltrated material in the cermet layer in the button cells are believed to be comparable. Since the amount of $\mathrm{Ni}(\mathrm{NiO})$ was very small, it was not possible to detect any signal with XEDS during the SEM investigation. However, as the results show, from electrochemical characterization (see details below), there was a dramatic effect with the small additions of $\mathrm{Ni}$ to the $\mathrm{CGO} 20$ solution. The microstructure of the infiltrated CGO20 phase was similar to the previously reported infiltration of CGO20 in STN backbone (14). Thus, it is believed that the CGO20 grains are only about $5 \mathrm{~nm}$ after infiltration and calcination at $350{ }^{\circ} \mathrm{C}$ and reaches a grain size of approximately $40 \mathrm{~nm}$ after electrochemical testing at $800^{\circ} \mathrm{C}$, similar to what was reported in ref. (14). The results are consistent with the grain sizes shown in Figure 2. The achieved small CGO20 grain sizes might be explained by a self-limited grain growth mechanism, similar to the results recently reported by Rupp et al. for nano-crystalline ceria ceramics (16). The limited grain growth was only observed for temperatures below $1100^{\circ} \mathrm{C}$ and average grain sizes below $140 \mathrm{~nm}$ (16). These finding are very interesting for metal supported SOFCs with regards to stability since they are to be used at temperatures $<800^{\circ} \mathrm{C}$ where self-limited grain growth of ceria seem to occur.

Electrochemical Characterization 
Symmetrical Cell Tests. Examples of impedance spectra, from symmetrical cells infiltrated with CGO20-Ni, obtained between $650{ }^{\circ} \mathrm{C}$ and $750{ }^{\circ} \mathrm{C}$ in $\mathrm{H}_{2}$ with approximately $3 \% \mathrm{H}_{2} \mathrm{O}$ are shown in Figure 3.

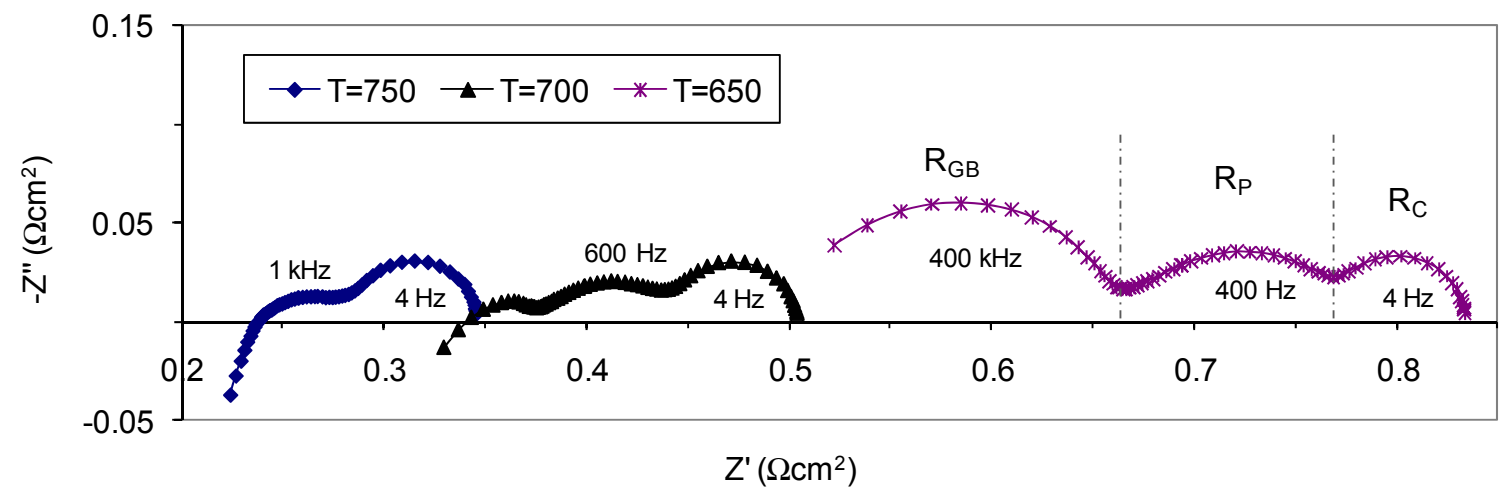

Figure 3. Selected impedance spectra from the symmetrical cells infiltrated with CGO20$\mathrm{Ni}$ at different temperatures in humidified $\mathrm{H}_{2}$ (approximately $3 \% \mathrm{H}_{2} \mathrm{O}$ ). All impedance spectra are corrected for the active electrode area (note that $\mathrm{R}_{\mathrm{S}}$ must be multiplied by a factor of two for comparison due to the symmetrical cell configuration). $\mathrm{R}_{\mathrm{GB}}=$ electrolyte grain boundary resistance, $\mathrm{R}_{\mathrm{P}}=$ electrode polarization resistance, $\mathrm{R}_{\mathrm{C}}=$ concentration polarization (related to test set-up). The frequency numbers indicate the approximate summit frequency of each arc.

From measurements at different temperatures and gas compositions it was found that the impedance data was best fitted to the equivalent circuit $(R Q)_{G B} L R_{S}(R Q)_{P}(R C)_{C}$, following the circuit description codes described elsewhere (17). The inductance, L, is ascribed to the leads and had a typical value of $2 \cdot 10^{-8} \mathrm{H}$ for the current measurement system. $R_{S}$ is ascribed to the series resistance of the symmetric cell, originating mainly from the ionic conductivity of the ScYSZ electrolyte. The magnitude of $R_{S}$ was as expected for an ScYSZ electrolyte of $120 \mu \mathrm{m}$ thickness in the investigated temperature range and the results were consistent for all samples. $\mathrm{R}_{\mathrm{GB}}$ was shown to originate from the contribution from the electrolyte grain boundaries. $\mathrm{R}_{\mathrm{C}}$ was in principle temperature independent, however, it was largely affected by changes in $\mathrm{pH}_{2}$ and/or $\mathrm{pH}_{2} \mathrm{O}$, indicating that this low frequency arc was associated with concentration polarization (related to the test set-up), thus, not related to the electrode polarization resistance $\left(R_{P}\right)$. The polarization resistances $\left(R_{P}\right)$ at $650{ }^{\circ} \mathrm{C}$ for the symmetrical cells with different infiltration solutions are shown in Table II. Only values for $650{ }^{\circ} \mathrm{C}$ are shown due to difficulties in doing the fitting of the impedance data for the other electrodes than those with CGO20-Ni (strong overlap of different semi-circles in the Nyquist plots).

Table II. Polarization resistance $\left(\mathrm{R}_{\mathrm{P}}\right)$ in $\Omega \mathrm{cm}^{2}$ for different electrode compositions (infiltrated material) measured with symmetrical cells. Each electrode composition was measured on 4 symmetrical cells to check reproducibility.

\begin{tabular}{cc}
\hline Electrode composition & $\mathbf{R}_{\mathbf{P}} @ \mathbf{6 5 0}^{\mathbf{}} \mathbf{C}\left(\mathbf{\mathbf { \Omega c m }} \mathbf{c m}^{\mathbf{}}\right)$ \\
\hline $\mathrm{CeO}_{2}$ & $5.1 \pm 0.3$ \\
$\mathrm{CGO} 20$ & $1.2 \pm 0.2$ \\
$\mathrm{CGO} 20-\mathrm{Ni}$ & $0.12 \pm 0.01$ \\
\hline
\end{tabular}


As can be seen in Figure 3 and Table II the $\mathrm{R}_{\mathrm{P}}$ for the CGO20-Ni infiltrated electrode was only $0.12 \Omega \mathrm{cm}^{2}$ and $0.06 \Omega \mathrm{cm}^{2}$ in humidified hydrogen at $650^{\circ} \mathrm{C}$ and $750{ }^{\circ} \mathrm{C}$, respectively. Furthermore, the apparent activation energy was calculated to $0.62 \pm 0.03$ $\mathrm{eV}$ in the temperature region from $650-750^{\circ} \mathrm{C}$, making the electrode especially suitable for intermediate temperature operation. $\mathrm{CGO} 20$ is a mixed ionic and electronic conductor (MIEC) and it is therefore believed that the CGO20 is responsible for the electrocatalytic activity with the additional aid of Ni working as a catalyst (18). It is worth noting that the polarization resistance decreased by one order of magnitude with the addition of only 10 wt.\% Ni (with respect to CGO20). The cermet layer structure, which is basically only an electronic conductor, is thus believed only to participate in the electrochemistry as a conductor for electrons. The infiltrated phase consisted of nano-sized particles (see Figure 2) and as a result there were active surfaces/facets in large numbers (14), giving rise to the achieved high activity of the CGO20 and CGO20-Ni-infiltrated cermet electrodes.

Fuel Cell Tests. Figure 4 shows polarization and power curves recorded at $655^{\circ} \mathrm{C}$ and $749^{\circ} \mathrm{C}$. The cell performance was very promising, showing significantly lower or at least comparable area specific resistance (ASR) values than that of many other metal supported SOFCs presented so far in the literature (see e.g ref. (1-11)). The ASR values are calculated as the secant value at $0.6 \mathrm{~V}$ at the different temperatures and reached 0.26 $\Omega \mathrm{cm}^{2}$ and $0.54 \Omega \mathrm{cm}^{2}$ at $749{ }^{\circ} \mathrm{C}$ and $655^{\circ} \mathrm{C}$ with hydrogen (with $4 \% \mathrm{H}_{2} \mathrm{O}$ ) as fuel and $\mathrm{O}_{2}$ as oxidant.

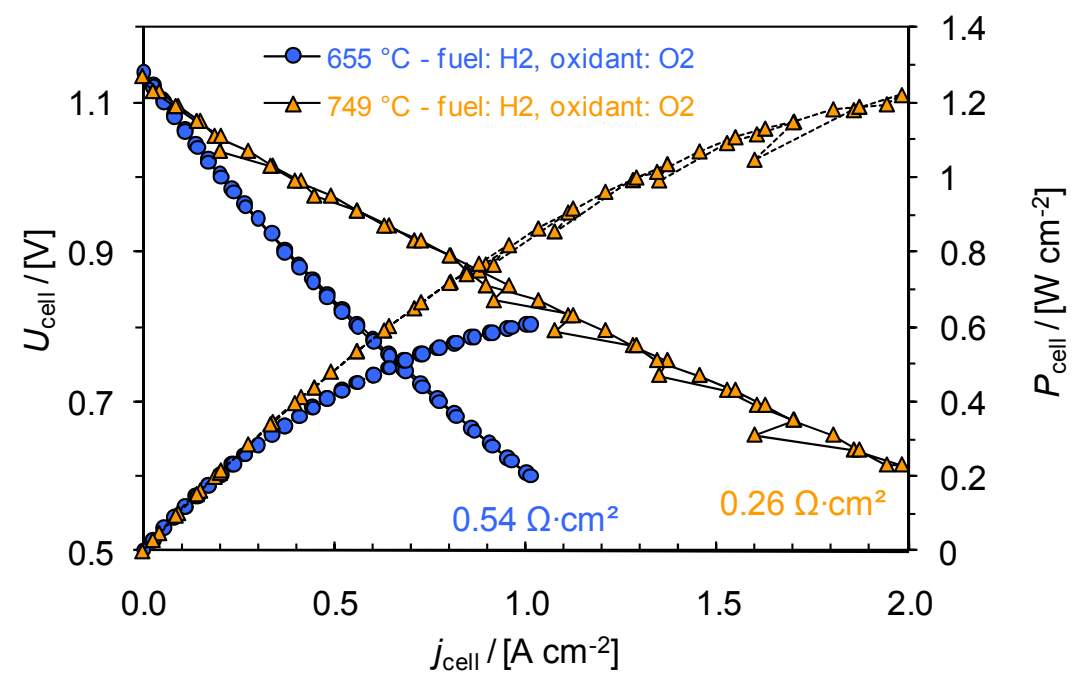

Figure 4. I-V and I-P characteristics of the metal supported button cell at $655^{\circ} \mathrm{C}$ and $749^{\circ} \mathrm{C}$. Humidified (approximately $\left.4 \% \mathrm{H}_{2} \mathrm{O}\right) \mathrm{H}_{2}$ as fuel and oxygen $\left(\mathrm{O}_{2}\right)$ as oxidant. The

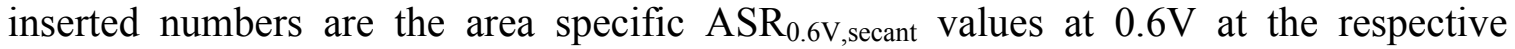
temperatures.

Figure 5 shows the evolution of the open circuit voltage (OCV) with time at $655^{\circ} \mathrm{C}$ and after thermal cyclings up to $\max 800^{\circ} \mathrm{C}$. The results showed that the button cell had good stability and nice electrolyte gas tightness with no significant increase of ASR with time or by spending up to $20 \mathrm{~h}$ at $800^{\circ} \mathrm{C}$. The thermal cyclings (between $650^{\circ} \mathrm{C}$ and $800^{\circ} \mathrm{C}$ ) were done at a rate of $240^{\circ} \mathrm{C} / \mathrm{h}$, a rate which only was limited by the test set-up. Furthermore, the cell voltage reached $>1250 \mathrm{mV}$ in dry hydrogen at a flow rate of $12 \mathrm{~L} \mathrm{~h}^{-1} \mathrm{~cm}^{-2}$ indicating a relatively gas tight cell. 


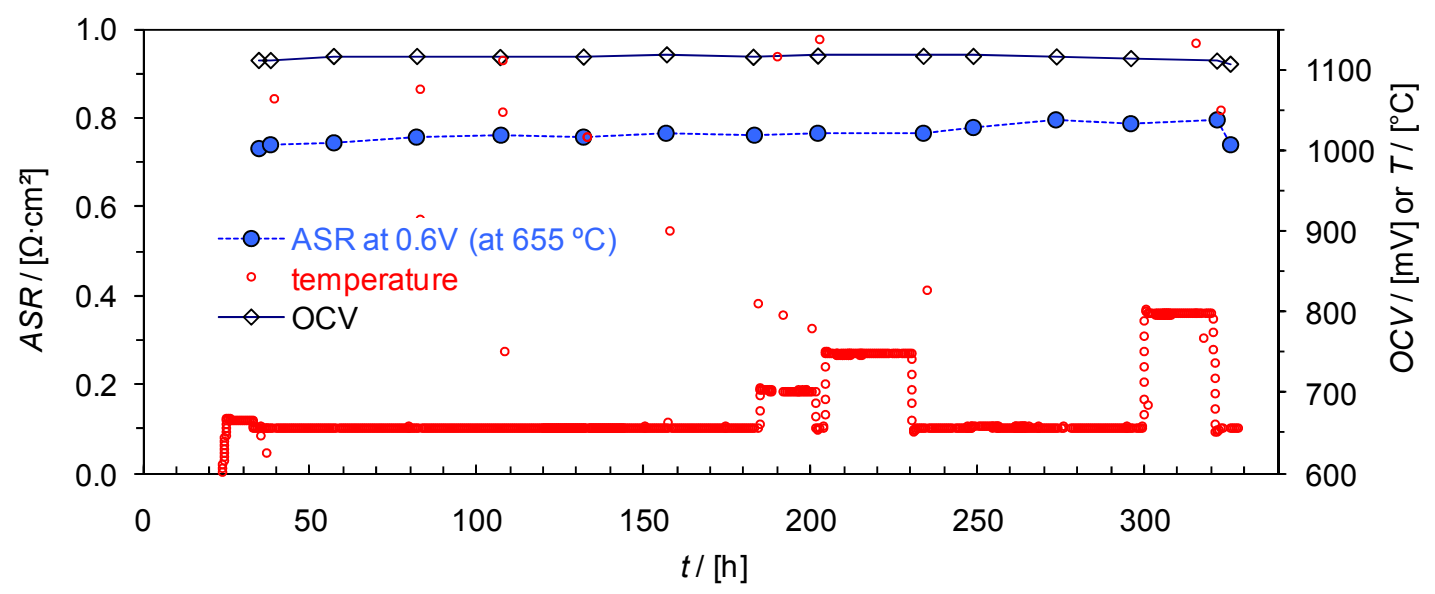

Figure 5. Evolution of the open circuit voltage (OCV) and $\mathrm{ASR}_{0.6 \mathrm{~V} \text {,secant }}$ at $655^{\circ} \mathrm{C}$ with time and after thermal cyclings up to $\max 800{ }^{\circ} \mathrm{C}$. Measurements in humidified (approximately $4 \% \mathrm{H}_{2} \mathrm{O}$ ) $\mathrm{H}_{2}$ as fuel and air as oxidant.

Figure 6 shows the evolution of the cell voltage with time under a constant current load of $0.25 \mathrm{Acm}^{-2}$ and $655^{\circ} \mathrm{C}$ for approximately $1000 \mathrm{~h}$. The galvanostatic durability test was conducted after the thermal cyclings shown in Figure 5. The degradation rate observed during testing at $0.25 \mathrm{Acm}^{-2}$ was $<5 \% / 1000 \mathrm{~h}$ based on the change in cell voltage during the testing period. Forthcoming reports will include more detailed analysis of the tested cells with more discussion about the possible degradation mechanisms.

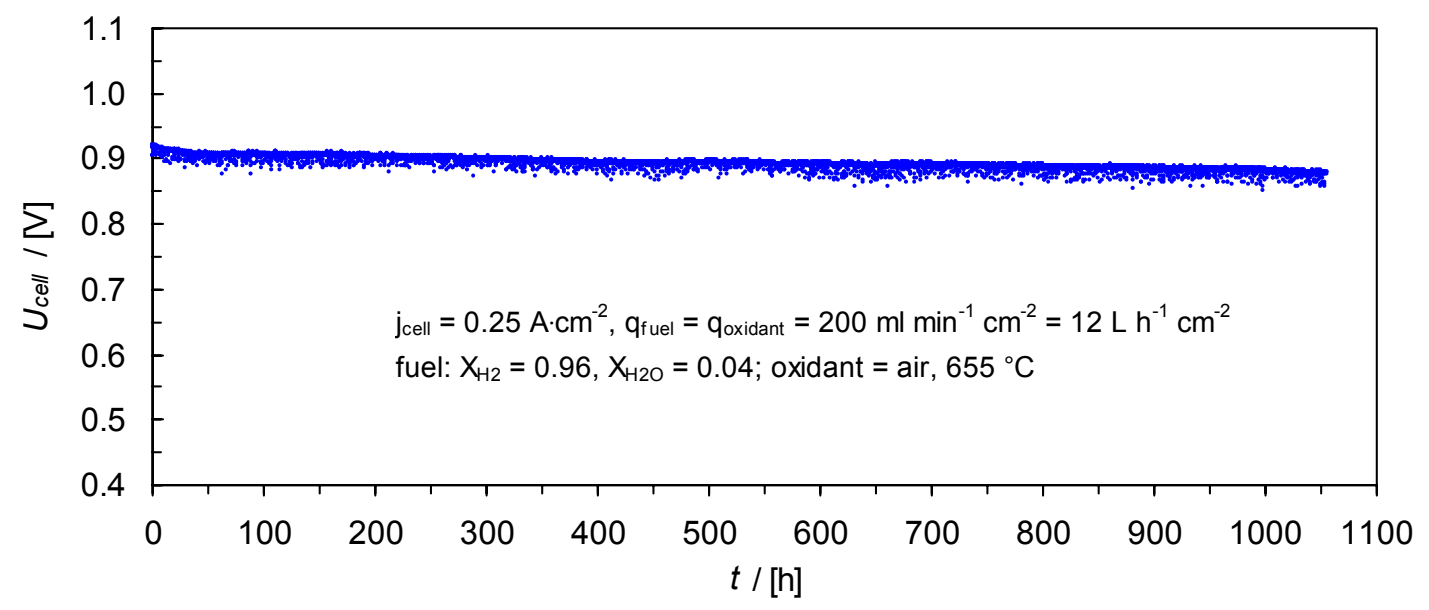

Figure 6. Durability of the metal supported button cell at $655^{\circ} \mathrm{C}$ and a current density of $0.25 \mathrm{~A} \mathrm{~cm}^{-2}$. Humidified (approximately $4 \% \mathrm{H}_{2} \mathrm{O}$ ) $\mathrm{H}_{2}$ as fuel and air as oxidant.

\section{Conclusions}

A novel metal supported SOFC design has been developed, comprising an anode structure, in which nano-sized ceria and nickel particles were formed in a backbone structure of an electronically conductive cermet phase. Nickel was only present in minor amounts to improve the catalytic activity, thereby making the anode structure less sensitive for Ni-agglomeration. The multilayered structure was successfully obtainable by 
conventional ceramic processing techniques such as tape-casting, screen printing, and sintering. The results from the symmetrical cells and button cell tests demonstrate fair long-term stability and excellent performance at intermediate temperatures.

\section{Acknowledgments}

Financial support by Topsoe Fuel Cell, the EU project FP7-211940 (METSOFC), and The Danish National Advanced Technology Foundation is gratefully acknowledged. We are thankful to the Fuel Cells and Solid State Chemistry Division at Risø-DTU for assistance.

\section{References}

1. M. C. Tucker, G. Y. Lau, C. P. Jacobson, L. C. DeJonghe, S. J. Visco, J. Power Sources, 171, 477 (2007).

2. R. Vassen, D. Hathiramani, J. Mertens, V. A. C. Haanappel, I. C. Vinke, Surf. Coat. Technol., 202, 499 (2007).

3. R. Vassen, H. Kassner, A. Stuke, F. Hauler, D. Hathiramani, D. Stoever, Surf. Coat. Technol., 202, 4432 (2008).

4. M. Lang, T. Franco, G. Schiller, N. Wagner, J. Appl. Electrochem., 32, 871 (2002).

5. M. Lang, P. Szabo, Z. Ilhan, S. Cinque, T. Franco, G. Schiller, J. Fuel Cell Science and Technology, 4, 384 (2007).

6. G. Schiller, T. Franco, M. Lang, P. Metzger, A. Stoermer, Meet. Abstr. Electrochem. Soc., 501, 1047 (2006).

7. G. Schiller, A. Ansar, M. Lang, O. Patz, J. Appl. Electrochem., 39, 293 (2009).

8. S. Hui, D. Yang, Z. Wang, S. Yick, C. Deces-Petit, W. Qu, et al, J. Power Sources, 167, 336 (2007).

9. N. P. Brandon, A. Blake, D. Corcoran, D. Cumming, A. Duckett, K. El-Koury, et al, J. Fuel Cell Science and Technology, 1, 61 (2004).

10. M. C. Tucker, G. Y. Lau, C. P. Jacobson, L. C. DeJonghe, S. J. Visco, J. Power Sources, 175, 447 (2008).

11. Y. B. Matus, L. C. De Jonghe, C. P. Jacobson, S. J. Visco, Solid State Ionics, 176, 443 (2005).

12. M. Brandner, M. Bram, J. Froitzheim, H. P. Buchkremer, D. Stoever, Solid State Ionics, 179, 1501 (2008).

13. H. Kurokawa, G. Y. Lau, C. P. Jacobson, L. C. De Jonghe, S. J. Visco, J. Mater. Process. Technol., 182, 469 (2007).

14. P. Blennow, K. K. Hansen, L. R. Wallenberg, M. Mogensen, ECS Trans., 13 (26), 181 (2008).

15. S. Linderoth, J. Electroceramics, 22, 61 (2009).

16. J. L. M. Rupp, A. Infortuna, L. J. Gauckler, Acta Mater., 54, 1721 (2006).

17. B. A. Boukamp, Solid State Ionics, 169, 65 (2004).

18. J. Rossmeisl, W. G. Bessler, Solid State Ionics, 178, 1694 (2008). 